\title{
Pengaruh Metode Demonstrasi terhadap Hasil Belajar IPA Kelas V MI-AL Ma'arif Kota Sorong
}

\author{
Setiawan Wijayanto ${ }^{1 \bowtie}$, Asrul $^{2 \&}$ Abdul Rachman Tiro ${ }^{3}$
}

Program Studi PGSD, Universitas Pendidikan Muhammadiyah Sorong, Indonesia

$\bowtie$ E-mail: Zhetiawan.reggae88@gmail.com

\begin{abstract}
Abstrak
Penelitian ini bertujuan untuk mengetahui pengaruh penerapan metode pembelajaran demonstrasi terhadap hasil belajar peserta didik kelas V. Metode yang digunakan dalam penelitian ini (experiment quasi). Sampel penelitian yaitu 15 peserta didik kelas VA sebagai kelas kontrol dan 15 peserta didik kelas VB sebagai kelas eksperimen. Teknik pengambilan data pada penelitian ini menggunakan teknik Purposive Sampling. Teknik pengumpulan data dalam penelitian ini menggunakan soal pre-test dan soal post-test. Teknik analisis data menggunakan hasil Uji t. Hasil analisis data diperoleh bahwa ratarata hasil belajar peserta didik kelas eksperimen lebih tinggi dari nilai rata-rata hasil belajar peserta didik kelas kontrol. Hasil perhitungan Uji N-Gain, menunjukkan bahwa nilai rata-rata nilai N-Gain score untuk kelas eksperimen (metode demonstrasi) adalah sebesar 51.1695 atau 51\% termasuk dalam kategori kurang efektif. Sementara untuk rata-rata N-Gain score untuk kelas kontrol adalah sebesar 38.4839 atau $38.5 \%$ termasuk dalam kategori tidak efektif. Hasil uji indipendent sample $t$ test diketahui nilai Sig. (2-tailed) sebesar 0.280 dan nilai $0.280>0,05$ maka H0 diterima, jadi dapat disimpulkan bahwa pembelajaran dengan menggunakan metode demonstrasi pada kelas eksperimen tidak terdapat perbedaan yang signifikan dengan kelas kontrol yang menggunakan metode konvensional.
\end{abstract}

Kata Kunci: Metode Pembelajaran; Demonstrasi; Hasil Belajar.

\begin{abstract}
.
This purpose of this study is to know the effect of implementing demonstration learning methods on learning outcomes of class $V$ students. The method used in this study (quasi experiment). The research sample was 15 students in class VA as the control class and 15 students in class VB as the experimental class. The data takimg technique in this study used purposive sampling technique. Data collection techniques in this study used pre-test questions and post-test questions. The data analysis technique used the results of the t test. The results of data analysis showed that the average learning outcomes of the experimental class students were higher than the average value of the control class students' learning outcomes. The results of the calculation of the N-Gain Test, show that the average value of the $\mathrm{N}$-Gain score for the experimental class (demonstration method) is 51.1695 or $51 \%$ is in the less effective category. Meanwhile, the average N-Gain score for the control class was 38.4839 or $38.5 \%$ in the ineffective category. The results of the independent sample t test show that the Sig. (2-tailed) of 0.280 and a value of 0.280>0.05, then HO is accepted, so it can be concluded that learning using the demonstration method in the experimental class has no significant difference with the control class using conventional methods.
\end{abstract}

Keywords: Learning Methods; Demonstration; Learning Outcomes. 


\section{PENDAHULUAN}

Keberhasilan pendidikan akan dicapai oleh suatu bangsa apabila ada usaha untuk meningkatkan mutu pendidikan, pemerintah sejauh ini telah berusaha melakukan perbaikan-perbaikan agar mutu pendidikan terus meningkat mengikuti perkembangan jaman, diantaranya dengan perbaikan kurikulum, penataran bagi guru-guru, penyempurnaan buku-buku pelajaran dan penambahan alat peraga, namun mutu pendidikan yang dicapai belum seperti yang diharapkan. Perbaikan yang telah dilakukan pemerintah akan berjalan kurang maksimal apabila tidak didukung dari berbagai pihak, seperti guru, orang tua siswa, siswa dan masyarakat yang turut serta dalam meningkatkan mutu pendidikan.

Peningkatan mutu pendidikan di sekolah berkaitan langsung dengan siswa sebagai anak didik dan guru sebagai pendidik. Menurut Ki Hajar Dewantara Pendidikan merupakan tututan bagi pertumbuhan anak-anak artinya, pendidikan menuntut segala kekuatan kodrat yang ada pada diri anak-anak, agar mereka sebagai manusia sekaligus sebagai anggota masyarakat dapat mencapai keselamatan dan kebahagiaan setinggi-tingginya (Susiloningsih, 2016).

Keberhasilan pendidikan dari intensitas siswa dalam belajar dan keberhasilan siswa dipengaruhi oleh beberapa faktor, diantaranya siswa itu sendiri, orang tua, serta guru. Seiring dengan perkembangan jaman dan kurikulum, guru dituntut untuk lebih berperan sebagai fasilitator, sedangkan peserta didik yang dituntut aktif dalam proses belajar-mengajar, akan tetapi pada kenyataannya guru masih mengalami kesulitan dalam memaksimalkan perannya sebagai pembelajar.

Hasil observasi yang dilakukan pada kelas V MI Al-ma'arif Kota Sorong ditemukan bahwa pembelajaran berlangsung terlihat guru menerangkan materi pelajaran peserta didik kurang memperhatikan dan mereka sibuk dengan aktivitas masing-masing seperti membolak-balik buku dan mencoret buku untuk menghilangkan kejenuhan. Hal tersebut terjadi akibat metode pembelajaran masih kurang memfokuskan peserta didik pada pembelajaran. Ketika guru mengajukan pertanyaan, hanya beberapa anak yang berani menjawab dan sebagian lagi hanya diam bahkan tidak mampu menjawab, hal ini menunjukan bahwa pembelajaran yang dilakukan masih kurang menarik.

Permasalahan dalam proses pembelajaran lebih jelas terlihat bahwa peserta didik kurang memahami materi, malu untuk bertanya, atau mengeluarkan pendapat, dan tidak memiliki keberanian untuk tampil kedepan kelas serta melakukan percobaan. Permasalahan tersebut memicu munculnya masalah lain yaitu interaksi dan komunikasi antara peserta didik dan guru tidak tercipta dengan baik, sehingga proses pembelajaran terlihat di dominasi oleh guru. Peserta didik cenderung belajar sendiri tanpa adanya tukar informasi dengan peserta didik lainya sehingga interaksi dan komunikasi peserta didik di kelas belum berlangsung secara optimal. Untuk mengatasi permasalahan ini, maka perlu adanya upaya perbaikan proses pembelajaran yang dapat menumbuhkan minat, motivasi, dan aktivitas belajar peserta didik sehingga dapat meningkatkan hasil belajar yang kurang optimal atau masih rendah. Sebuah solusi dimana peserta didik dapat berperan serta aktif dalam proses pembelajaran, menggunakan kreatifitas dalam proses membangun pengetahuan dan pemahaman mereka, sehingga pengalaman ini tidak hanya bertahan dalam jangka waktu yang sementara. Salah satunya dengan menerapkan metode pembelajaran demonstrasi.

Metode Demonstasi adalah metode mengajar dengan cara memperagakan 
barang, kejadian, aturan dan urutan melakukan kegiatan, baik secara langsung maupun melalui penggunaan media pengajaran yang relevan dengan pokok bahasan atau materi yang sedang disajikan.

Keunggulan metode demonstrasi adalah terjadinya verbalisme akan dapat dihindari, peserta didik diarahkan untuk langsung memperhatikan bahan pelajaran yang dijelaskan, proses pembelajaran akan lebih menarik, dengan cara mengamati secara langsung, peserta didik akan memiliki kesempatan untuk membandingkan antara teori dan kenyataan. (Agus Eka Saputra \& Slamet Priyanto, 2016). Menurut Fikria Trisnawaty dan Slameto keunggulan metode demonstrasi antara lain yaitu memusatkan perhatian sehingga membuat pengajaran menjadi lebih jelas dan konkrit, selain itu lebih melekatkan pengalaman dan kesan sebagai hasil pembelajaran dalam diri peserta didik, serta membuta proses pengajaran lebih menarik.(Fikria Trisnawaty dan Slameto, 2016)

Metode pembelajaran demonstrasi selain menambah semangat peserta didik untuk belajar juga memiliki pengaruh yang besar terhadap hasil belajar peserta didik. Hasil belajar merupakan kemampuan-kemampuan harus yang diperoleh peserta didik setelah mereka mengikuti proses belajar-mengajar tentang mata pelajaran tertentu dalam aspek kognitif, aspek afektif dan aspek psikomotor (Widayanti, 2013). Pendapat yang lain memperkuat bahwa hasil belajar terutama bidang IPA membutuhkan pembelajaran yang melibatkan siswa untuk aktif dalam kelas (Asrul, 2020).

\section{METODE PENELITIAN}

Jenis penelitian ini adalah penelitian Kuantitatif dengan metode eksperimen quasi yang melibatkan dua kelas, yaitu kelas eksperimen dan kelas kontrol. Kelas eksperimen adalah kelas yang mendapat perlakuan berupa metode pembelajaran demonstrasi sedangkan kelas kontrol adalah kelompok kelas yang menerapkan pembelajaran langsung seperti biasa. Populasi yang diambil dalam penelitian ini adalah seluruh siswa kelas V MI Al-Ma'arif Kota Sorong. Subjek dalam penelitian ini adalah kelas VA yang berjumlah 15 peserta didik sebagai kelas eksperimen dan kelas VB yang berjumlah 15 peserta didik sebagai kelas kontrol, jenis penelitian adalah eksperimen quasi.

Desain penelitian yang digunakan dalam penelitian ini adalah Nonequivalent Control Group Design. Sebelum pelaksanaan eksperimen, peneliti memberikan pre-test kepada sampel yang telah ditentukan. Setelah itu, diberikan perlakuan kepada kelompok eksperimen kemudian diakhiri dengan memberikan post-test pada sampel tersebut, dan pada kelas kontrol hanya diberikan soal pre-test dan post-test.

\section{HASIL DAN PEMBAHASAN}

Berdasarkan hasil penelitian yang dilakukan di MI Al-ma'arif Kota Sorong, sampel yang digunakan untuk penelitian ini adalah kelas VB dengan jumlah 15 peserta didik sebagai kelas eksperimen dan kelas VA dengan jumlah 15 peserta didik sebagai kelas kontrol. Penelitian ini adalah penelitian eksperimen quasi dengan melibatkan 2 kelas, yaitu kelas eksperimen dan kelas kontrol. Kelas eksperimen adalah kelas yang mendapat perlakuan berupa metode pembelajaran demonstrasi sedangkan kelas kontrol adalah kelompok kelas yang menerapkan pembelajaran langsung seperti biasa. Penelitian ini merupakan penelitian eksperimen oleh karena itu sebelum responden diberi perlakuan, terlebih dahulu diberikan soal pre-tets pada kedua kelas sampel untuk mengetahui hasil awal peserta 
didik, setelah itu peserta didik pada kelas eksperimen diberi perlakuan berupa metode pembelajaran demonstrasi yang dilakukan sebanyak dua kali pertemuan, setelah perlakuan selesai peserta didik diberikan soal post-test untuk melihat hasil apakah ada perbedaan dan pengaruh dari kelas kelas kontrol yang diberi pengajaran seperti biasa dan kelas eksperimen yang diberi perlakuan berupa metode pembelajaran demonstrasi. Tujuan dari penelitian ini adalah untuk mengetahui pengaruh penggunaan motode pembelajaran demonstrasi terhadap hasil belajar IPA di MI-Al Ma'arif kota Sorong. Subjek dalam penelitian ini adalah kelas VA yang berjumlah 15 peserta didik sebagai kelas eksperimen dan kelas VB yang berjumlah 15 peserta didik sebagai kelas kontrol, jenis penelitian adalah eksperimen quasi.

Tabel 1. Analisis Statistic deskriptif

\begin{tabular}{llllll}
\hline Descriptive Statistics & & & & & \\
\hline & N & Min & Max & Mean & $\begin{array}{l}\text { Std. } \\
\text { Devia } \\
\text { tion }\end{array}$ \\
\hline Pre-test Eksperimen & 15 & 36 & 75 & 63.47 & 11.332 \\
Post-test Eksperimen & 15 & 65 & 100 & 82.53 & 11.704 \\
Pre-test Kontrol & 15 & 26 & 80 & $\mathbf{6 2 . 6 7}$ & 14.251 \\
Post-test Kontrol & 15 & 65 & 100 & 77.93 & 11.183 \\
Valid N (listwise) & 15 & & & & \\
\hline
\end{tabular}

Berdasarkan tabel 1, dapat dikemukakan nilai dari kelas Eksperimen pada hasil pre-test yaitu nilai minimal sebesar 36, nilai maksimal 75 , nilai rata-rata (mean) sebesar 63,47, dan pada hasil post-test yaitu nilai minimal sebesar 65 , nilai maksimal 100 , nilai rata-rata (mean) sebesar 82,53. Sedangkan nilai dari kelas Kontrol pada hasil pre-test yaitu nilai minimal sebesar 26, nilai maksimal 80 , nilai rata-rata (mean) sebesar 62,67, dan pada hasil post-test yaitu nilai minimal sebesar 65, nilai maksimal 100, nilai rata-rata (mean) sebesar 77,93.

Data hasil belajar awal diperoleh sebelum diberi perlakuan dan data hasil belajar akhir diperoleh setelah diberikan perlakuan, yaitu penggunaan metode demonstrasi pada kelas eksperimen dan metode konvensional pada kelas kontrol. Hasil belajar peserta didik diukur dengan soal pre-test dan post-test. Berikut adalah data hasil belajar peserta didik kelas eksperimen dan kelas kontrol.

Uji normalitas dignakan untuk mengetahui apakah data yang diperoleh dari masing-masing variabel berdistribusi normal atau tidak. Perhitungan uji normalitas menggunakan rumus Shapiro-Wilk dengan taraf signifkan 0,05. Seluruh proses perhitungan dilakukan dengan komputer program SPSS V.16 for Windows. Uji normalitas dilakukan terhadap skor pre-test dan post-test peserta didik. Kriteria yang digunakan jika hasil $\mathrm{p}>0,05$ maka distribusi frekuensi tersebut normal, sebaliknya jika hasil $\mathrm{p}<0,05$ maka distribusi frekuensi tidak normal. Untuk memperoleh hasil uji normalitas, digunakan data nilai pre-test dan post-test peserta didik, kemudian data diolah menggunakan aplikasi SPSS V.16 for Windows.

Data menunjukkan bahwa pre-test dapat diketahui kelas eksperimen memperoleh nilai signifikansi 0.19 dan kelas kontrol memperoleh nilai 0.18. Hasil tersebut menunjukan bahwa nilai signifikansi kelas eksperimen dan kelas kontrol >0.05, maka dapat disimpulkan data hasil pre-test kelas eksperimen dan kontrol berdistribusi normal. Pada data hasil post-test dapat diketahui bahwa kelas eksperimen memperoleh nilai signifikansi 0.308 dan kelas kontrol memperoleh nilai 0.053. Hasil tersebut menunjukan bahwa nilai signifikansi kelas eksperimen dan kelas kontrol >0.05, maka dapat disimpulkan data hasil post-test kelas eksperimen dan kontrol berdistribusi normal.

Uji homogenitas bertujuan untuk mengetahui apakah suatu varians (keberagaman) data dari dua atau lebih kelompok bersifat homogen (sama) atau heterogen (tidak sama), dalam penelitian ini, uji homogenitas digunakan untuk mengetahui apakah varians data post-test kelas 
eksperimen dan data post-test kelas kontrol bersifat homogen atau tidak. Berdasarkan nilai signifikansi (Sig.) Based On Mean sebesar $0.751>0.05$, sehingga dapat disimpulkan bahwa varians data post-test kelas eksperimen dan data post-test kelas kontrol adalah sama atau homogen.

\section{Uji N-Gain}

Uji N-Gain dilakukan untuk mengetahui perbandingan nilai pre-test dan post-test serta untuk mengetahui keefektifan penggunaan metode demonstrasi yang digunakan.

Tabel 2. Hasil Perhitungan skor N-gain kelas eksperimen dan kelas kontrol

\begin{tabular}{lllll}
\hline No & Kelas eksperimen & \multicolumn{3}{l}{ Kelas kontrol } \\
\cline { 2 - 5 } & Nama & N-gain skor (\%) & Nama & N-gain skor (\%) \\
\hline 1. & A S A & 14.29 & A F & 0.00 \\
2. & A A M & 66.67 & A J M & 66.67 \\
3. & A & 100.00 & A Q N & 57.50 \\
4. & A N H & 60.00 & A N F & 0.00 \\
5. & A F N & 45.95 & D T A & 45.95 \\
6. & D A R & 100.00 & E S & 0.00 \\
7. & D M S & 32.69 & H R P F & 51.92 \\
8. & F N R & 32.69 & I A & 45.76 \\
9. & F W N & 20.00 & I F S & 100.00 \\
10. & K A H H & 40.00 & L A & 0.00 \\
11. & K N A & 57.14 & M F & 0.00 \\
12. & M L & 3.85 & N N & 0.00 \\
13. & N K P & 33.33 & S K P & 100.00 \\
14. & R M & 100.00 & S H & 43.24 \\
15. & S A R & 60.94 & T I & 66.22 \\
\hline & Rata-rata & $\mathbf{5 1 . 1 6 9 5}$ & Rata-rata & $\mathbf{3 8 . 4 8 3 9}$ \\
\cline { 2 - 5 } & Minimal & $\mathbf{3 . 8 5}$ & Minimal & $\mathbf{0 . 0 0}$ \\
\cline { 2 - 5 } & Maksimal & $\mathbf{1 0 0 . 0 0}$ & Maksimal & $\mathbf{1 0 0 . 0 0}$ \\
\hline
\end{tabular}

Berdasarkan hasil perhitungan Uji NGain pada tabel 2, menunjukkan bahwa nilai rata-rata nilai $\mathrm{N}$-Gain score untuk kelas eksperimen (metode demonstrasi) adalah sebesar 51.1695 atau $51 \%$ termasuk dalam kategori kurang efektif, dengan nilai $\mathrm{N}$-Gain score minimal 3.85\% dan maksimal $100 \%$. Sementara untuk rata-rata $\mathrm{N}$-Gain score untuk kelas kontrol adalah sebesar 38.4839 atau $38.5 \%$ termasuk dalam kategori tidak efektif, dengan nilai $\mathrm{N}$-Gain score minimal $0 \%$ dan maksimal 100\%. Maka dapat disimpulkan bahwa penggunaan metode demonstrasi kurang efektif untuk meningkatkan hasil belajar dalam pelajaran IPA materi Organ pencernaan manusia dan hewan pada siswa kelas V MI Al-ma'arif kota sorong. Sementara penggunaan metode konvensional tidak efektif untuk meningkatkan hasil belajar dalam pelajaran IPA materi Organ pencernaan manusia dan hewan pada siswa kelas V MI Al-ma'arif kota sorong.

Uji Indipendent Sample T test digunakan untuk mengetahui apakah terdapat perbedaan rata-rata dua sampel yang tidak berpasangan, dengan ketentuan jika nilai signifikasi $>0,05$ maka $\mathrm{H}_{0}$ diterima dan jika nilai signifikasi yang diperoleh $<0,05$ maka $\mathrm{H}_{1}$ diterima, adapun hipotesisnya sebagai berikut;

$\mathrm{H}_{0} \quad=$ Tidak ada pengaruh metode pembelajaran Demonstrasi terhadap hasil belajar IPA peserta didik kelas V MI Al-ma'arif Kota Sorong.

$\mathrm{H}_{1}=$ Ada pengaruh metode pembelajaran Demonstrasi terhadap hasil belajar IPA peserta didik kelas V MI Al-ma'arif Kota Sorong. 
Tabel 3. Hasil uji t

\begin{tabular}{|c|c|c|c|c|c|c|c|c|c|c|}
\hline \multicolumn{11}{|c|}{$\begin{array}{c}\text { Independent Samples Test } \\
\end{array}$} \\
\hline & & \multicolumn{2}{|c|}{$\begin{array}{l}\text { Levene's Test } \\
\text { for Equality of } \\
\text { Variances }\end{array}$} & \multicolumn{7}{|c|}{ t-test for Equality of Means } \\
\hline & & & & & & & & & $\begin{array}{r}95^{\circ} \\
\text { Confid } \\
\text { Interval } \\
\text { Differe }\end{array}$ & $\begin{array}{l}\% \\
\text { ence } \\
\text { of the } \\
\text { ence }\end{array}$ \\
\hline & & $\mathrm{F}$ & Sig. & $\mathrm{T}$ & Df & $\begin{array}{l}\text { Sig. (2- } \\
\text { tailed) }\end{array}$ & $\begin{array}{c}\text { Mean } \\
\text { Differenc } \\
\mathrm{e}\end{array}$ & $\begin{array}{l}\text { Std. } \\
\text { Error } \\
\text { Differ } \\
\text { ence }\end{array}$ & Lower & $\begin{array}{c}\text { Upp } \\
\text { er }\end{array}$ \\
\hline \multirow{2}{*}{$\begin{array}{l}\text { hasil } \\
\text { belajar } \\
\text { siswa }\end{array}$} & $\begin{array}{l}\text { Equal variances } \\
\text { assumed }\end{array}$ & 103 & .751 & 1.101 & 28 & 280 & 4.600 & 4.180 & -3.962 & 3.162 \\
\hline & $\begin{array}{l}\text { Equal variances } \\
\text { not assumed }\end{array}$ & & & 1.101 & 27.942 & .280 & 4.600 & 4.180 & -3.963 & 3.163 \\
\hline
\end{tabular}

Berdasarkan tabel 3 diketahui nilai Sig. KESIMPULAN

(2-tailed) sebesar 0.280 dan nilai $0.280>$

0,05 maka $\mathrm{H}_{0}$ diterima, jadi dapat disimpulkan bahwa pembelajaran dengan menggunakan metode demonstrasi pada kelas eksperimen tidak terdapat perbedaan yang signifikan dengan kelas kontrol yang menggunakan metode konvensional.

Jika kita bandingkan dengan penelitian terdahulu yang dilakukan oleh Dimas Endar Septian (2017) di Kelas 5 SD N 1 Panggang Gunungkidul". Berdasarkan hasil pengujian dapat peroleh t hitung 6,995 dengan nilai sig sebesar 0,00. Oleh karena t hitung 6,995 > t tabel 2,131, dan nilai signifikansi $0,000<$ 0,05, maka hasil ini menunjukkan terdapat perbedaan yang signifikan. Maka dari itu metode demonstrasi memberikan pengaruh yang positiv terhadap kemampuan gerakan salat peserta didik kelas 5 SD N 1 Panggang.

Dari perbandingan penelitian lain yang dilakukan oleh Diman Endar Septian (2017) dengan yang dilakukan oleh peneliti, dapat disimpulkan bahwa kondisi pandemi Covid19 yang berlangsung selama jalannya penelitian sangat berdampak pada proses penelitian, sehingga penerapan metode demonstrasi yang diterapkan tidak terdapat perbedaan yang signifikan dengan metode konvensional.
Berdasarkan hasil penelitian dan pembahasan, maka dapat disimpulkan bahwa terdapat pengaruh metode pembelajaran demosntrasi terhadap hasil belajar peserta didik kelas V MI Al-Ma'arif kota Sorong, namun tidak memiliki perbeddan pengaruh yang signifikan antara pembelajaran demonstrasi dengan pembelajaran konvensional pada kelas V mata pelajaran IPA.

\section{DAFTAR RUJUKAN}

Agus Eka Saputra \& Slamet Priyanto. (2016). "Penerapan Metode Demonstrasi Dan Media Film Untuk Meningkatkan Keaktifan Dalam pembelajaran Dan Prestasi Belajar Sistem Rem, "Jurnal Taman Vokasi, $4(2), 4$.

Aisyah. (2014). Pengaruh Metode Demonstrasiuntuk Menngkatkan Hasil Belajar Ipa Siswa Pada Materi Pembiasan Cahaya. Skripsi. Program Studi Pendidikan Guru Madrasah Ibtidaiyah Jurusan Kependidikan Islam Fakultas Ilmu Tarbiyah Dan Keguruan Universitas Islam Negeri Syarif Hidayatullah Jakarta.

Arikunto, S. (2010). Prosedur Penelitian Suatu Pendekatan Praktik. Jakarta: Rineka Cipta.

Asrul, A., Tiro, A. R., \& Risakotta, H. (2020). Pengaruh Model Pembelajaran 
Inkuiri Terbimbing terhadap Hasil Belajar IPA pada Materi Panca Indra Manusia Bagi Siswa Kelas IV SD Inpres 12 Kabupaten Sorong. Jurnal Papeda: Jurnal Publikasi Pendidikan Dasar, 2(1), 37-42.

Dimas Endar Septian. (2017). Pengaruh Metode Demonstrasi Dalam Pembelajaran Pendidikan Agama Islam Terhadap Kemampuan Gerakan Salat Siswa Kelas 5 Sd N 1 Panggang Gunungkidul. Skripsi. Fakultas Ilmu Tarbiyah Dan Keguruan Universitas Islam Negeri Sunan Kalijaga Yogyakarta.

Djamarah, Syaiful Bahri Dan Aswan Zain. (2010). Strategi Belajar Mengajar. Jakarta: Rineka Cipta.

Elektro, J. T., Teknik, F., \& Semarang, U. N. (2015)"Penggunaan Model Demonstrasi Dalam Materi Ajar Instalasi Sistem Operasi," Jurnal Dinamika 5(3), hal. dj6-13.

Fikria Trisnawaty Dan Slameto. (2017)"Peningkatkan Hasil Belajar Ipa Melalui Penggunaan Metode Demonstrasi Pada Siswa Kelas $4 \mathrm{Sd}$," Jurnal Satya Widya 33(1), hal. 37-44.

Gafur, A., Smpn, G., \& Nggoang, S. (2018) "Peningkatan Hasil Belajar IPA Terpadu Melalui Metode Demonstrasi Pada Siswa Kelas Viii Smp Negeri 2 Sano Nggoang Manggarai Barat Tahun Pelajaran 2017/2018," Jurnal Ilmu Sosial dan Pendidikan 2(1), hal. 144161.

Hanafy, S., Tarbiyah, F., Uin, K., Makassar, A., Ii, K., Sultan, J.,Email, S. (2014) "Konsep Belajar Dan Pembelajaran," Jurnal Lentera Pendidikan 17(1), hal. 66-79.

Kumala. Nur Farida. (2016). Pembelajaran IPA Sekolah Dasar. Malang: Edisi Infografika.

Nuraini, F. Dan R. F. (2016) "Hubungan Antara Aktivitas Belajar Siswa Dan Hasil Belajar Pada Mata Pelajaran Kimia Kelas X Sma Negeri 5 Pontianak," Ar-Razi Jurnal Ilmiah (Februaru 2018) 6(1).
Padangsidimpuan, I. (2017)"Belajar Dan Pembelajaran," Jurnal Kajian Ilmuilmu Keislaman (Desember 2017), 03(2), 333-352.

Pindo Hutauruk, R. S. (2018)"Meningkatkan Hasil Belajar Siswa Dengan Alat Peraga Pada Mata Pelsudjaajaran IPA Kelas IV SDN Nomor 14," School Education Journal (Juni 2018), 8(2).

Roestiyah. (2012). Strategi Belajar Mengajar. Jakarta: Rineka Cipta.

Sudjana, N. (2013). Dasar - Dasar Proses Belajar Mengajar. Bandung: Sinar Baru Algensindo.

Sugiyono. (2012). Memahami Penelitian Kualitatif. Penerbit CV. Alfabeta: Bandung.

Sugiyono. (2015). Metode Penelitian Pendidikan (Pendekatan Kuantitatif, Kualitatif Dan $R \& D)$. Penerbit CV. Alfabeta: Bandung.

Sugiyono. (2016). Metode Penelitian Kuantitatif, Kualitatif Dan R\&D. Bandung: PT Alfabet.

Susiloningsih, W. (2016). "Model Pembelajaran Ctl ( Contextual Teaching And Learning ) Dalam Meningkatkan Hasil Belajar Mahasiswa Pgsd Pada Matakuliah Konsep IPS Dasar." Jurnal Pedagogia 5(1), hal. 57-66.

Suprijono. (2013). Cooperative Learning. Yogyakarta: Pustaka Pelajar.

Tiflah Addina Khairiah NST. (2018) Pengaruh Metode Demonstrasi Terhadap Hasil Belajar Siswa Pada Mata Pelajaran IPA Sub Bahasan Cahaya Dan Sifat-Sifatnya Di Kelas V Min Medan Tembung Tahun Pelajaran 2017/2018. Skripsi. Fakultas Ilmu Tarbiyah Dan Keguruan Universitas Islam Negeri Sumatera Utara Medan.

Widayanti, L. (2013). "Problem Based Learning Pada Siswa Kelas Viia 